\title{
Proposal of an applicable ZVT Quadratic Boost Converter Topology in Renewable Energies.
}

\author{
Mikael N. Oliveira ${ }^{1}$, Diego F. Rodrigues ${ }^{2}$ and Lúcio R. Barbosa ${ }^{1}$ \\ ${ }^{1}$ Department of Electrical Engineering \\ State University of Londrina \\ Campus Universitário - Londrina, (Brazil) \\ e-mail: l.barbosa@uel.br, mikael.n.f.oliveira@gmail.com \\ ${ }^{2}$ City Hall of Cambé \\ Otto Gaertner Street, 65 (Brazil) \\ e-mail: diego.francisco@live.com
}

\begin{abstract}
In this paper, a new active snubber cell is proposed to contrive a new quadratic Boost pulse width modulated (PWM) converter. This snubber cell provides zero voltage transition (ZVT) for the main switch of a converter. A New ZVT-PWM Quadratic Boost converter equipped with the proposed snubber cell provides most the desirable features of ZVT converters presented previously, and overcomes most the drawbacks of these converters providing a large voltage step-up. Subsequently, the new converter can operate with soft switching successfully at very wide line and load ranges and at considerably high frequencies. Moreover, the main devices do not have any additional voltage and current stresses. In this study, a detailed analysis of the new converter is presented, and this theoretical analysis is verified exactly by simulation and a prototype converter.
\end{abstract}

\section{Key words}

Quadratic converters, soft switching, zero voltage transition.

\section{Introduction}

New technological developments require power supplies with wide conversion ratios, for example, in portable applications and photovoltaic arrays [1]. The rapid growth of portable equipment has been fuelled by the strong customer demand of new features; however, the above has resulted in an increase on the power demand from the battery [2]. Many portable types of equipment require the converter to operate off the voltage of a single cell, which may impose the significant challenge. Also, fuel cells are attractive alternatives to combustion engines for electrical power generation, the full cell uses some sort of chemical fuel to its energy source, but like a battery, the chemical energy is directly converted to electrical energy, without the messy and inefficient combustion step. However, besides the obvious advantages of the fuel system in terms of higher efficiency, fuel diversification and environmental friendliness, this source of energy produces widely varying low DC voltage [3, Chs. 8-10]. Therefore, potential application is to convert the low-dc energy source of fuel cells $(25-45 \mathrm{~V})$ into suitable utilization current, voltage, and frequency for use by utility loads. Thus, this low voltage range must be transformed into a sufficient dc link voltage (350-400 VDC) so that it can be inverted into ac power to the grid.

In theory, wide DC conversion ratios can be obtained by properly adjusting the modulating control signal of the DC-DC switch-mode converter [4, 5, Ch. 1]. In practice, the maximum and the minimum attainable conversion ratios for the conventional converters are limited by the turn-on time and turn-off time of the switching devices. Also, the effective duty ratios range is limited by the conductions losses of both devices and inductors switching. On the other hand, an often-used approach is to use step-up transformers; however, large switching surges appear that may damage the switching devices and make the controller difficult to design. In addition, the transformer itself would limit the switching frequency of the switch-mode DC-DC converter.

The topology that provides a wide voltage ratio is the cascade convert, which consists in two or more basic DCDC switch-mode converters connected in cascade with the corresponding increase in power losses and control complexity $[6,7]$. The quadratic converter is an interesting topology, which uses a single active switch where the voltage ratio is given as a quadratic function of the duty ratio. In the technical literature, there is a discussion of topologies of converters with wide conversion ratios [8]; however, switching frequency should be increased by decreasing switching losses to achieve higher power density and faster transient response in well-known pulse width modulated (PWM) quadratic $\mathrm{dc}-\mathrm{dc}$ converters. This aim can be realized by using soft switching (SS) techniques instead of hard switching (HS) techniques. SS techniques are implemented by snubber 
cells, and basically provide zero voltage switching (ZVS) or zero current switching (ZCS) for semiconductor devices in these converters [8]-[14].

The normal zero voltage transition (ZVT) PWM converter [15] had been presented to implement the ZVS turn on process of the main switch during a very short ZVT time provided with a resonance. Recently, a zero voltage transition (ZVT) commutation cell was presented in [16] to provide ZVT for the main switch. It has many good features, then it was used to propose a ZVT Boost PWM converter featuring voltage conversion ratio with quadratic dependence on the duty cycle. The quadratic Boost converter in Fig. 1 can be used in large voltage step-up applications, since the dc voltage conversion ratio is given by $M(D)=D /(1-D)^{2}[17]$.

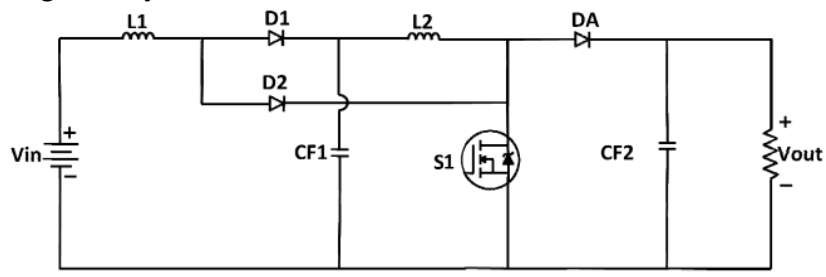

Fig. 1. Quadratic Boost Converter

The features of the proposed converter are discussed in this paper, and the principle of operation, simulation, and experimental results is presented to validate the proposed solution.

\section{Proposed Structure}

A configuration of the proposed structure is shown in Figure 2. This converter is based on the quadratic boost converter, integrated with the proposed soft switching auxiliary circuit.

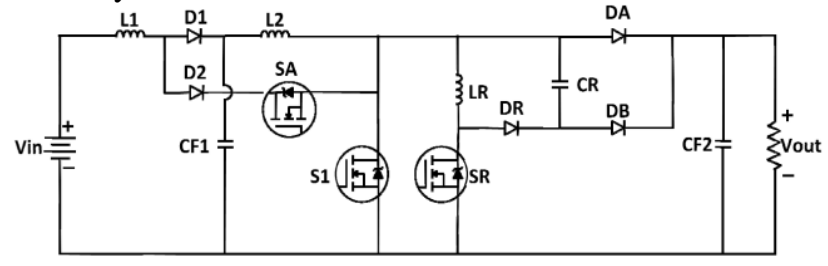

Fig. 2. SS Quadratic Boost Converter

\section{A. Circuit Description}

As the proposed structure is derived from the quadratic boost converter, there are two filter inductors (L1 and L2) and two filter capacitors (CF1 and CF2) for each stage. The SS cell is shown in Fig. 3, and a resonant inductor (LR), resonant capacitor (CR), auxiliary diodes (DR and DB) and auxiliary switch (SR) compose it. Another auxiliary switch (SA) was added in order to prevent diode D2 assume resonant current after S1 turning off, what would cause a voltage across the main switch during its turning off, preventing soft switching (ZVT).

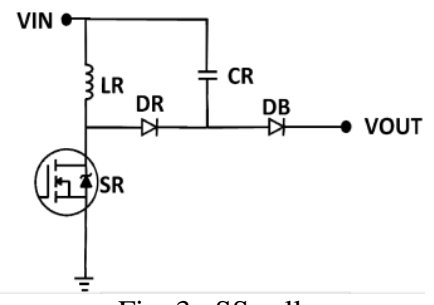

Fig. 3. SS cell
To simplify the analysis, it is assumed that the converter is operating in steady state and the following assumptions are made during one switching cycle: 1) The input voltage is pure dc, and 2) All components are ideal, thus the efficiency is $100 \%$. 3) All capacitors are sized to have a relatively small voltage ripple at the switching frequency. Based on these assumptions, the circuits of Fig. 4(a)-(g) are analyzed next.

\section{B. Operation Stages}

Seven stages occur over one switching cycle in the steady state operation of the proposed converter. The key waveforms concerning these stages are shown in Fig. 5. The detailed analysis of this converter is presented as follows.

1) Stage $\Delta T 1$ (Fig. 4a): The first stage of operation begins when the resonant switch (SR) is turned on in a ZCS way, thus the current in the resonant inductor (LR) increases linearly up to reach the current value in the inductor two (L2). The stage ends when the resonant current reaches L2 current and diode DA turns off with ZVS at $\mathrm{t}=\mathrm{t} 1$.

2) Stage $\Delta T 2$ (Fig. 4b): This stage starts when the current in L2 equals the current in LR, therefore DB is off. The auxiliary switch (SA) remains open to prevent the diode D2 conduct which would cause the converter had problems in its operation. Inductor LR remains charged with a constant current, while it starts storing stage of the inductor L2. In the meantime, the main switch is turned on in a ZCS and ZVS way.

3) Stage $\triangle T 3$ (Fig. 4c): This stage begins when SR is turned off and starts the resonance between LR and the resonant capacitor (CR). At this moment SA is also turned on, thereby the main switch S1 assumes the currents of the inductors L1 and L2.

4) Stage $\Delta T 4$ (Fig. 4d): This mode begins when resonant capacitor voltage reaches output voltage, then diode DB is turned on. This stage ends when resonant inductor current becomes zero.

5) Stage $\Delta T 5$ (Fig. 4e): The main switch is conducting the input current. All diodes are blocked, and the filter inductors stores energy.

6) Stage $\triangle T 6$ (Fig. 4.f): At the instant, switch $\mathrm{S} 1$ is turned off in a ZVS way, and the energy stored in the filter inductor L2 is transferred to the output capacitor CF2 through the diode $\mathrm{DB}$ and to the resonant capacitor $\mathrm{CR}$. In this time interval, CR linearly discharges to zero voltage.

7) Stage $\triangle T 7$ (Fig. 4g): In this stage, diode DA conduces the L1 current. The duration of this stage is defined by switch modulation. At the end of this time interval, switch SR turns on, and the next operating cycle begins.

The static gain, which represents the ratio between the output and the input voltages is function of the duty cycle, can be obtained by analyzing the waveforms of the inductor L1 and L2 observing the time intervals. The following definitions are assumed: 


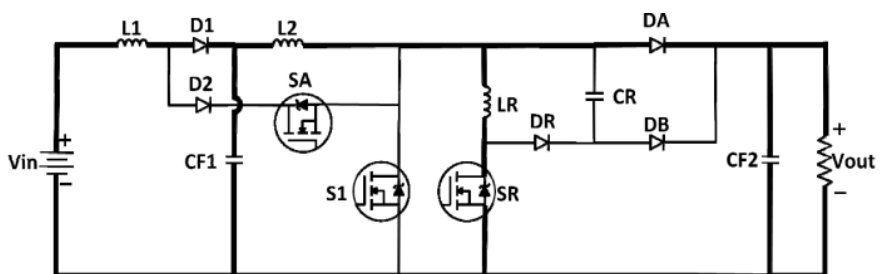

(a)

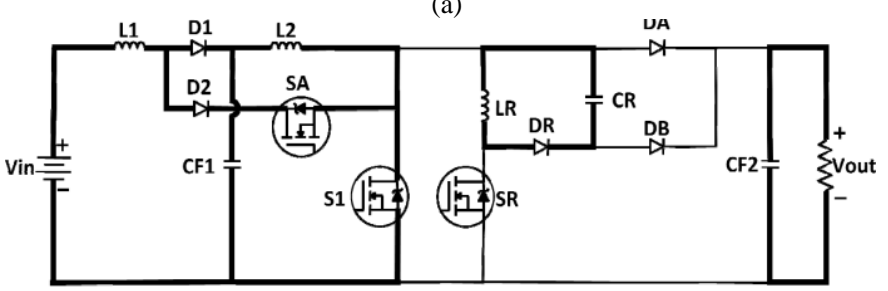

(c)

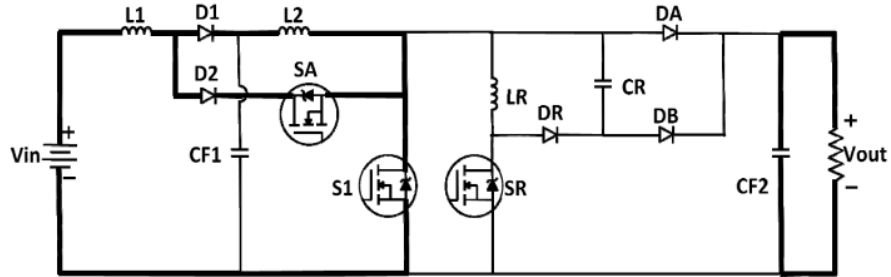

(e)

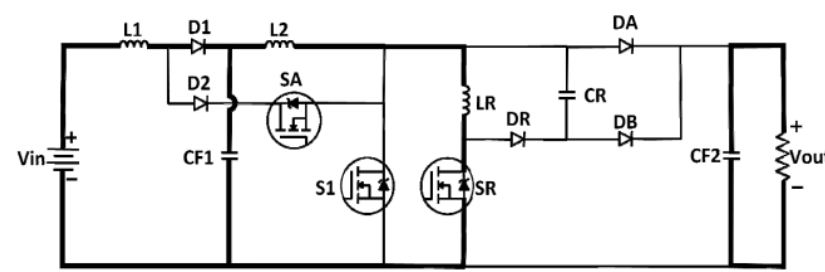

(b)

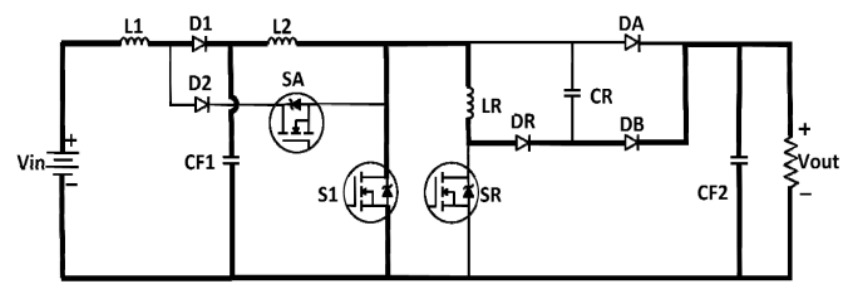

(d)

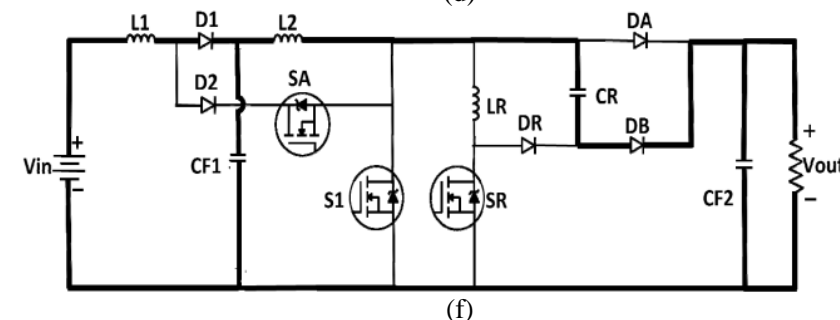

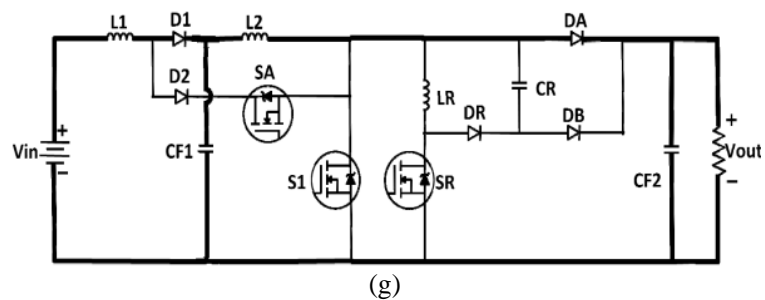

Fig. 4. Equivalent circuits of the operation stages in the proposed converter.

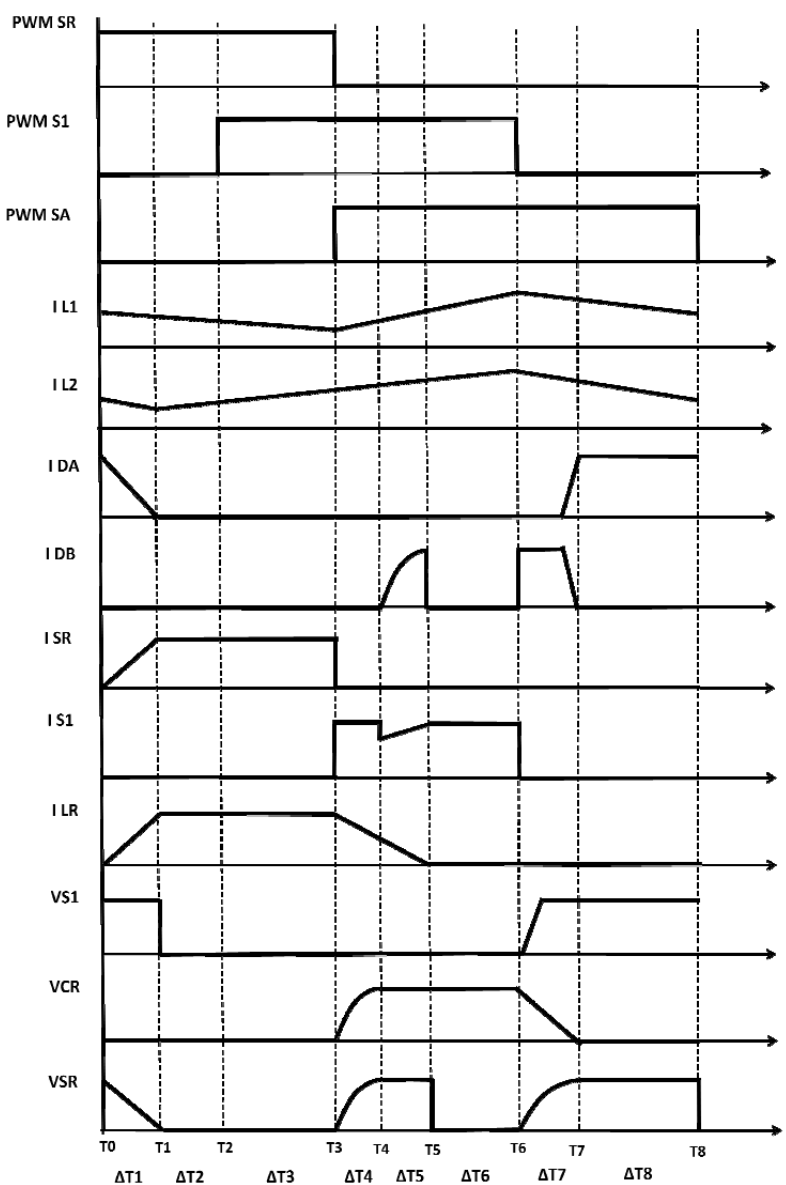

Fig. 5. Key waveforms concerning the operation stages.

$$
\begin{aligned}
\omega_{0} & =\sqrt{\frac{1}{C_{R} \cdot L_{R}}} \\
\alpha & =\frac{I_{L 1}}{V_{\text {out }}} \sqrt{\frac{L_{R}}{C_{R}}}
\end{aligned}
$$

After the mathematical analyses, the expression of the static gain can be obtained.

$$
\begin{gathered}
G_{1}=\frac{V_{\text {out }}}{V_{C F 1}}=\frac{1}{1-D-\frac{1}{T_{s} \omega_{0}}\left(-\alpha+\frac{1}{2 \alpha}\right)} \\
G_{2}=\frac{V_{C F 1}}{V_{\text {in }}}=\frac{1}{1-D-\frac{1}{T_{s} \omega_{0}}\left(-\alpha+\frac{1}{\alpha\left(1+G_{1}\right)}\right)} \\
G=\frac{V_{\text {out }}}{V_{\text {in }}}=G_{1} G_{2}
\end{gathered}
$$

Where:

$\mathrm{T}_{\mathrm{s}} \quad$ - Switching period.

D - Duty cycle.

The expression of the static gain is illustrated in Fig. 6 . 


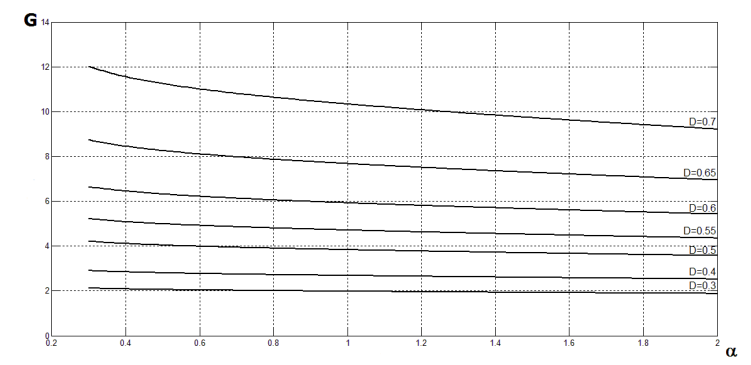

Fig. 6. Static gain curves.

According to the expressions, it appears clearly that total static gain $G$ is always higher compared to the conventional boost converter. Thus, it seems more appropriate to develop the new quadratic converter, which has high conversion ratio in a large range of duty cycle.

\section{Design Procedure}

Design of conventional quadratic PWM converters has been well presented in literatures. Thus, it is more significant to focus on design procedures of the auxiliary circuit. The resonant inductors and resonant capacitor are the most important components when designing the auxiliary circuit. The proposed auxiliary resonant circuit provides soft-switching conditions for the main switch. The following design procedure is developed considering procedures such as those presented previously in [18].

Snubber inductor $L_{R}$ is selected to allow its current increases from zero to the maximum $L_{2}$ current within $t_{r}$ time periods, during the turn-on of the auxiliary switch. It can be written.

$$
L_{R}(t) \geq \frac{V_{0}}{I_{\text {L2máx }}} t_{r}
$$

Here $t_{r}$ is the rise time of the transistor. This equation provide ZCS turn-on for the transistor.

Snubber capacitor $C_{r}$ is selected to be discharged from $\mathrm{V}_{\text {out }}$ to zero with the maximum input current over at least the time period $t_{\mathrm{f}}$ during the turn-off of the transistor. For this state, it is obttained:

$$
C_{R} \geq \frac{I_{L 2 m a ́ x}}{V_{C F 1}} t_{f}
$$

Here, $t_{f}$ is the fall time of the transistor.

\section{Simulation and Experimental Results}

A prototype of the proposed converter, as shown in Fig. 2, has been built in the laboratory. The newly proposed converter operates with an input voltage $\mathrm{Vi}=19 \mathrm{~V}$, output voltage $\mathrm{Vo}=200 \mathrm{~V}$, output power $300 \mathrm{~W}$, and a switching frequency of $100 \mathrm{KHz}$. The converter is simulated using simulation software PSIM. The major parameters and components are given in Table 1.

Figures7(a)-7(c) show the simulation results of the proposed converter and Figures 8(a)-8(c) present the experimental results.

Table I. - Components used and major parameters

\begin{tabular}{|l|l|l|}
\hline \multicolumn{1}{|c|}{ Components } & \multicolumn{1}{c|}{ Simulated } & \multicolumn{1}{c|}{ Experiment } \\
\hline Switches & Ideal & IRFP460 \\
\hline Diodes & Ideal & MUR1560 \\
\hline Resonant inductor (LR) & $15 \mathrm{uH}$ & $15 \mathrm{uH}$ \\
\hline Resonant inductor $(\mathrm{Lr} 2)$ & $3.5 \mathrm{nH}$ & $3.5 \mathrm{nH}$ \\
\hline Resonant capacitor $(\mathrm{Cr})$ & $4,7 \mathrm{nF}$ & $4,7 \mathrm{nF}$ \\
\hline Filter inductor (L1) & $559 \mathrm{uH}$ & $559 \mathrm{uH}$ \\
\hline Filter inductor (L2) & $1.8 \mathrm{mH}$ & $1.8 \mathrm{mH}$ \\
\hline Filter capacitor $(\mathrm{CF} 1)$ & $680 \mathrm{uF}$ & $680 \mathrm{uF}$ \\
\hline Output capacitor $(\mathrm{CF} 2)$ & $100 \mathrm{uF}$ & $100 \mathrm{uF}$ \\
\hline
\end{tabular}
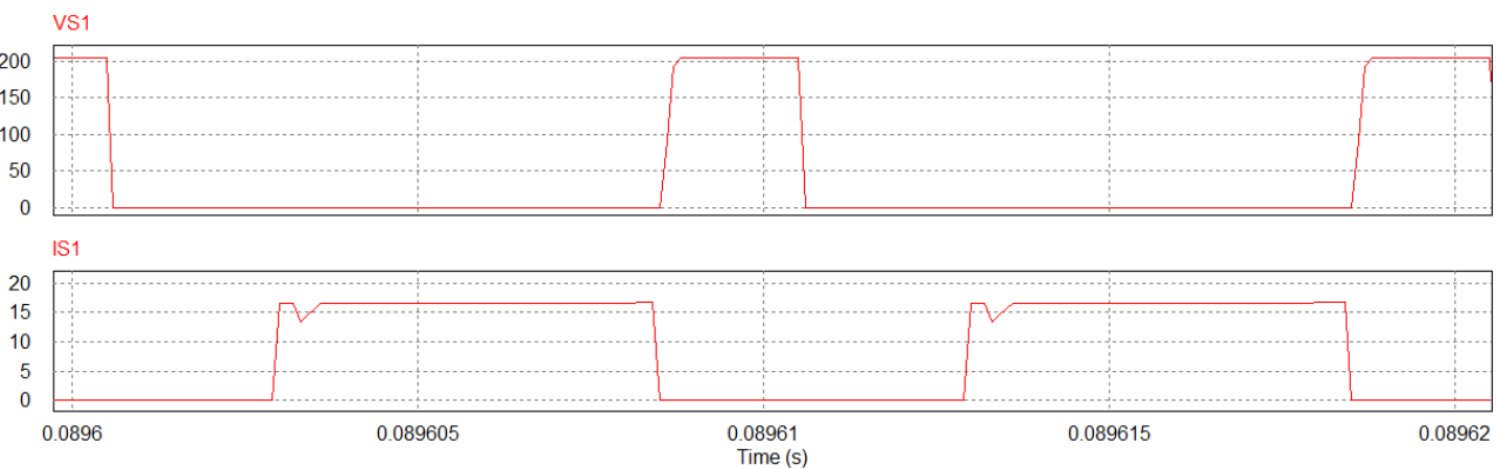

(a)

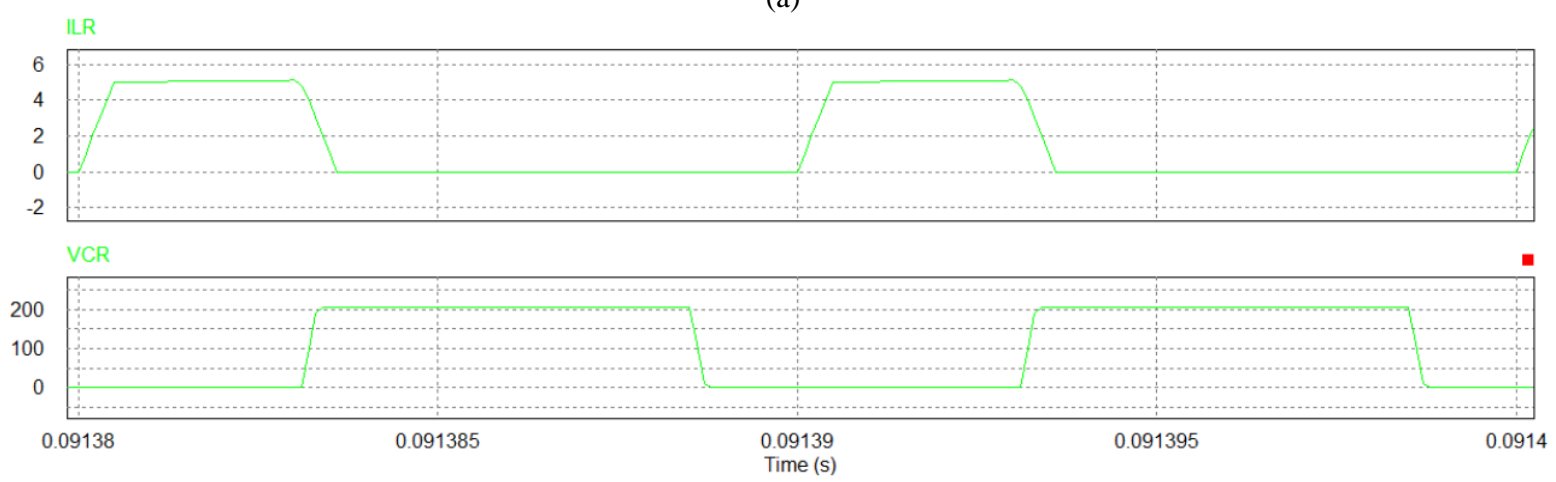

(b) 


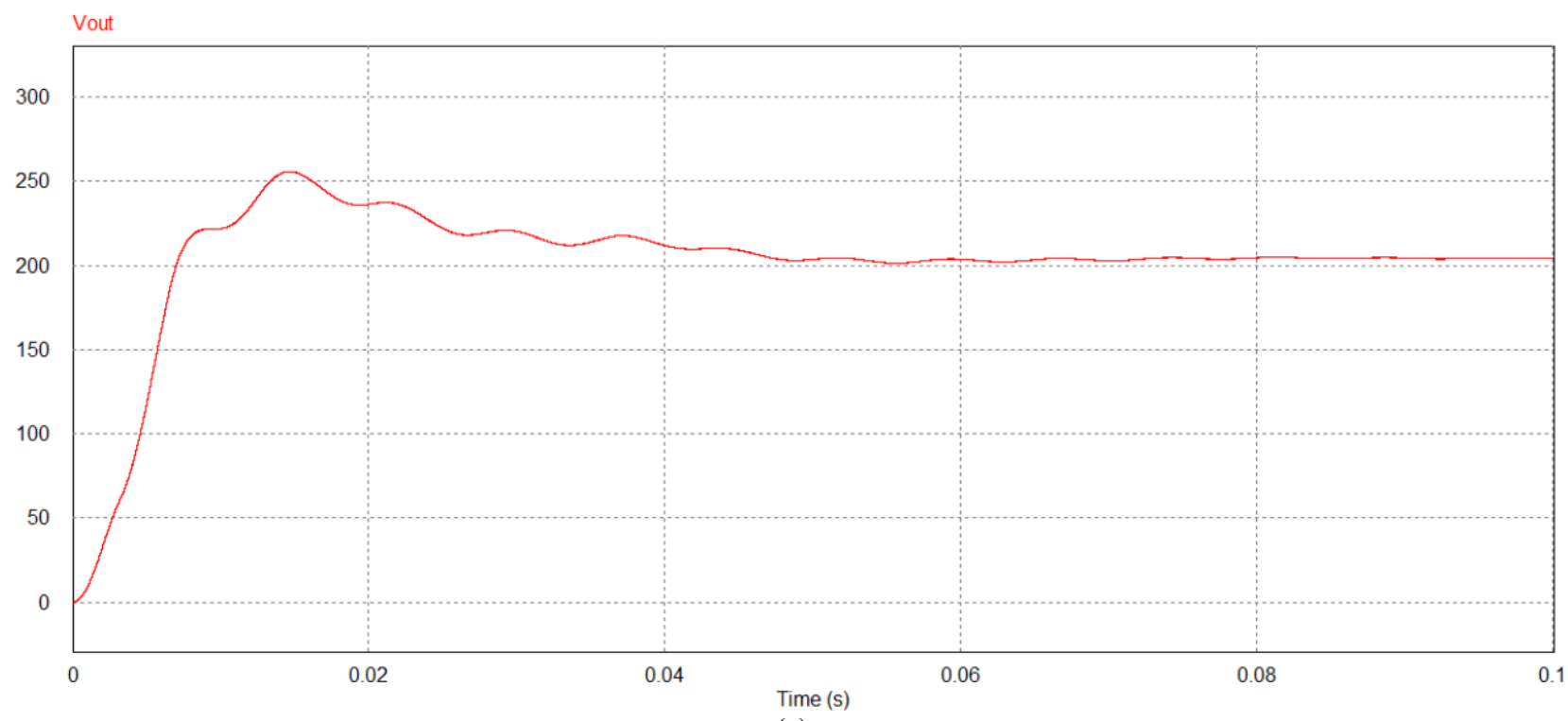

(c)

Fig. 7. Simulated waveforms.

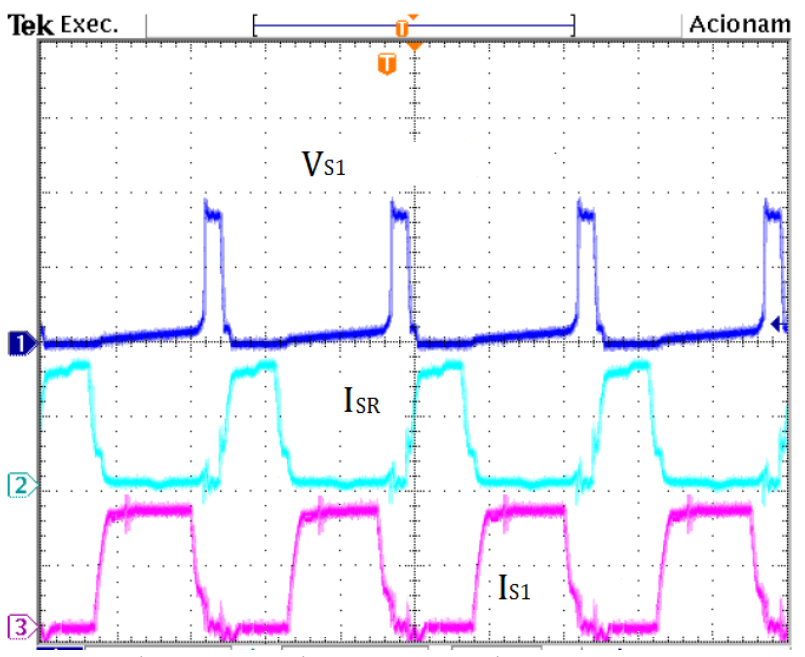

(a) Ch1 100V; Ch2 $10 \mathrm{~A} \Omega$ e $\mathrm{Ch} 35 \mathrm{~A} \Omega$

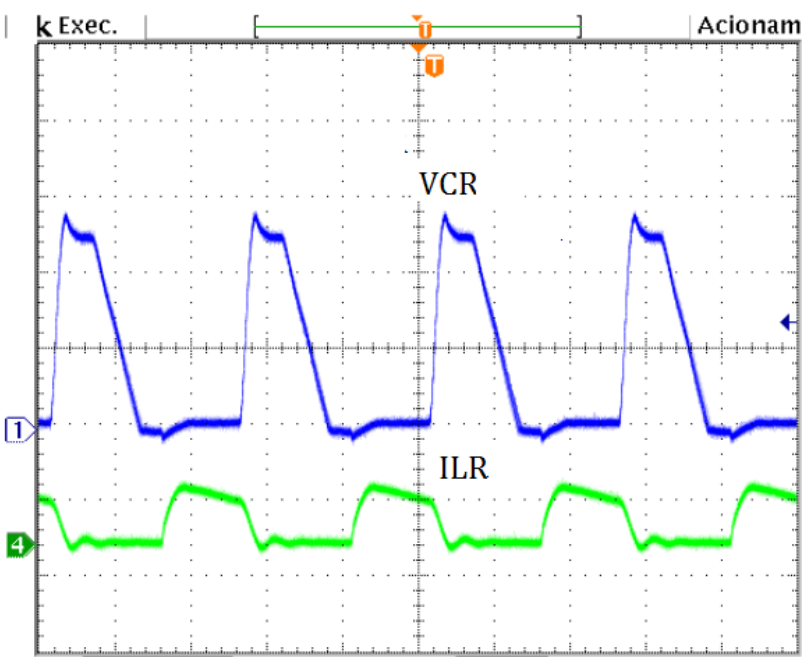

(b) Ch1 100V; Ch4 $5 \mathrm{~A} \Omega$

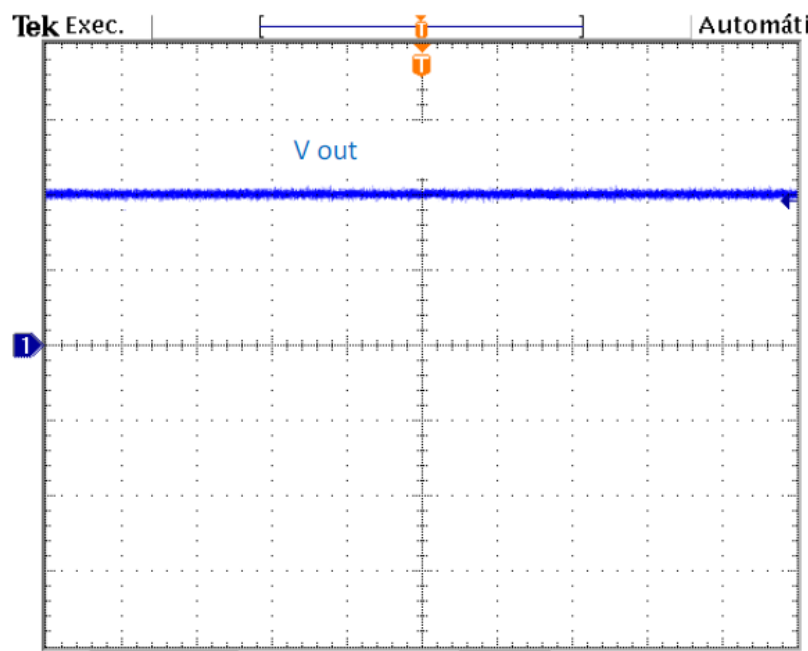

(c) $\mathrm{Ch} 1100 \mathrm{~V}$

Fig. 8. Experimental waveforms.

It is noted from Figures 7(a) and 8(a) that the main switch $\mathrm{S} 1$ is turned on under ZCS and ZVS. The main switch takes the input current just after the auxiliary switch SR turns off. The resonant inductor starts to transfer its stored energy to resonant capacitor during the turn-on period of main switch. The converter has not exceeded the voltage limits. The main switch also switches off under ZVS. The current and voltage wave shapes are identical to theoretical waveforms. 
It can be seen in Figures 7(b) and 8(b) that after main switch is turned off under ZVS, capacitor $\mathrm{Cr}$ is discharged to zero. From Figures 7(c) and 8(c) one can see the output voltage reaches $201 \mathrm{~V}$.

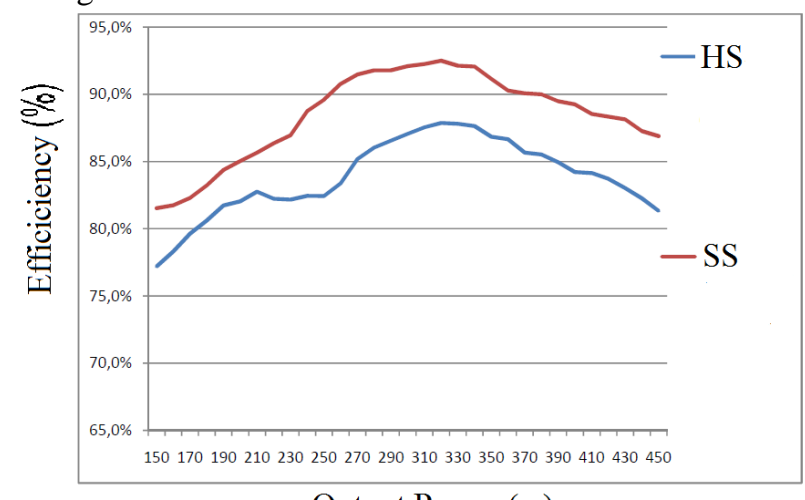

Output Power (w)

Fig. 8. Efficiency curves of the proposed SS and the HS converters compared

From Fig. 8, it is seen that the overall efficiency of the new converter reaches a value of $93 \%$ at nominal output power of $300 \mathrm{~W}$ and a switching frequency of $100 \mathrm{kHz}$. It is also seen that the efficiencies at low output powers are relatively higher than most of the other SS converters. Because converter loss is dependent strongly on circulating energy generally, and it is very low and also it becomes lower as the load current falls in the new converter.

\section{Conclusion}

In this study, a new active snubber cell that provides ZVT turn on for the main switch of a quadratic boost converter is presented to contrive a PWM converters. This new snubber cell is implemented by using only one resonant circuit without an important increase in cost and complexity. Novel ZVT-PWM quadratic boost converter equipped with the proposed snubber cell combines most of the desirable features of both ZVT and Quadratic converters presented previously, with high step-up voltage. Subsequently, semiconductor devices operate under soft switching; the main devices are subjected to no additional voltage and current stresses. This new converter operates successfully under light load conditions for the whole line and load ranges and at very high frequencies.

Consequently, novel ZVT-PWM quadratic boost converter equipped with the proposed new snubber cell was analyzed in detail. It was observed that the operation principles and the theoretical analysis of this converter were exactly verified by a prototype of a $450 \mathrm{~W}$ and $100 \mathrm{kHz}$. Thus, in this situation, one can conclude that significant efficiency improvements can be achieved with the application of the proposed soft commutation cell. Should clearly indicate advantages, limitations and possible applications in renewable energy sources.

\section{Acknowledgement}

The authors gratefully acknowledge the CNPq (National Council of Scientific and Technological Development) by the financial support.

\section{References}

[1] Sernia PC, Walker GR: 'Cascaded DC-DC converter connection of photovoltaic modules', IEEE Trans. Power Electron., 2004, 19 (4), pp. 1130-1139

[2] E. Wells, Jordan M : 'Low power boost converter for portable applications'. Unitrode Seminar 1200, Topic 2, 2001

[3] Hoogers G .: 'Fuel cell technology handbook' (CRC Press, 2002)

[4] Rashid MH: 'Power electronics handbook' (Academic Press, 2007, 2nd edn.)

[5] Moham TM, TM Undeland, Robbins WP:. 'Power electronics: Converters, Applications and Design "(John Wiley \& Sons, New York, 2003, 3rd edn.)

[6] H. MATSUO, HARADA K .: 'The cascade connection of switching regulators, "IEEE Trans. Ind. Appl., 1976, 12 (2) p. 192-198

[7] Morales. A, Carbajal-Gutierrez EE, Levya-RamosJ .: 'Modeling of switch-mode DC-DC converters cascade' IEEE Trans. Aerosp. Electron. Syst. 2002, 38 (1) p. 295-299

[8] D. Maksimovic, S. Cuk: 'Switching converters with wide DC conversion range ', IEEE Trans. Power Electron., 1991, 6 (1), pp. 151-157.

[9] W. McMurray, "Selection of snubbers and clamps to optimize the design of transistor switching converters", IEEE Trans. Industry Applications, vol 1A-19, no 4, July/August 1980.

[10] F. Lee, "High Frequency Quasi-Resonant Converter Technologies", Proceeding of the IEEE, vol 76, no4, April 1988.

[11] I. Barbi, J. Bolacel, D. Martins, F. Libano "Buck quase Resonant Converter Operating at Constant Frequency: Analysis, Design and Experimentation" IEEE PESC record, pp. 874-880, 1989

[12] L. Barbosa, E. Coelho, L. Freitas, J. Vieira, and V. Farias "PWM soft-switched converters with a single active switch" Trans. of IEEJ, Inc. (Industry Applications society)", vol. 117D, no11, pp. 1305-1310, November, 1997.

[13] J. Lambert, L. Barbosa, E. Coelho, L. Freitas, J. Vieira, and V. Farias "A Boost PWM Soft-single-Switched Converter with low voltage and current stresses" IEEE Trans. on Power Electron., vol.13, no1, pp. 16-35, January 1998

[14] L. Barbosa, A. Pereira, J. Rossi and M. Almeida "A Stressless Buck Quadratic PWM Soft Switched Converter" IEEE Intelec Record, pp. 150-155, 2002.

[15] G. Hua, C. S. Leu, Y. Jiang, and F. C. Lee, "Novel zerovoltage-transition PWM converters," IEEE Trans. Power Electron., vol. 9, pp. 213-219, Mar. 1994

[16] L.Barbosa, "A zero voltage transition interleaved boost converter and application to a PFC", Advances in Power Electronics, vol.2011, pp. 1-10, 2011.

[17] L. Barreto; E. Coelho; V. Farias; L. Freitas; J. Vieira Jr. "An Optimal Lossless Commutation Quadratic PWM Boost Converter", Applied Power Electronics Conference and Exposition, APEC 2002, Dallas, March, 2002, pp. 624-629.

[18] L. Barbosa, "Analysis of a soft-switched quadratic boost converter." Eletrônica de Potência, Campo Grande, v. 18, n.3, p.1047-1054, jun./ago.2013. 